\title{
Resistance of stored grain insect pests to active substances used in Poland for protection of stored grains
}

\section{Odporność szkodników magazynowych na substancje czynne insektycydów stosowanych w Polsce do ochrony magazynowanego ziarna}

\author{
Paweł Olejarski ${ }^{1}$, Paweł Węgorek ${ }^{2}$
}

\begin{abstract}
Summary
In the years 2010-2012 were tested resistance of the granary weevil (Sitophilus granarius L.) and the confused flour beetle (Tribolium confusum Duv.) to active substance of insecticides used in Poland. The insects were collected from warehouses located throughout whole the country. The granary weevil was collected from 21 locations and the confused flour beetle from 11 locations. Tests of resistance to contact insecticides deltamethrin and pirimiphos-methyl were carried out according with IRAC (Insecticide Resistance Action Committee) Susceptibility Test Method No. 6. Phosphine resistance test was performed according with method of Detia Degesch in special testers "Phosphine Resistance Test Kit". Two cases of resistance to deltamethrin of some individuals of granary weevil were found. No cases of wholly resistance of the studied populations of pests to pirimiphos-methyl or for phosphine were reported. Most of tested populations of the granary weevil and the confused flour beetle demonstrated a reduced susceptibility to deltamethrin and pirimiphos-methyl. Only a few individuals of the granary weevil demonstrated a reduced susceptibility to phosphine.
\end{abstract}

Key words: stored product pests, resistance, contact insecticides, phosphine

\section{Streszczenie}

W latach 2010-2012 prowadzono badania odporności wołka zbożowego (Sitophilus granarius L.) i trojszyka ulca (Tribolium confusum Duv.) na substancje czynne insektycydów stosowanych w Polsce. Materiał badawczy pozyskiwano z magazynów zlokalizowanych na terenie kraju. Chrząszcze wołka zbożowego zebrano z 21 lokalizacji, a trojszyka ulca z 11 lokalizacji. Badania odporności na deltametrynę i pirymifos metylowy prowadzono według metodyki IRAC (Insecticide Resistance Action Committee) nr 6, a na fosforowodór wykonano według metodyki firmy Detia Degesch i stosując testery „Phosphine Resistance Test Kit”. Stwierdzono dwa przypadki odporności pojedynczych osobników wołka zbożowego na deltametrynę. Nie odnotowano przypadków pełnej odporności wśród badanych populacji szkodników na pirymifos metylowy i fosforowodór. Stwierdzono zmniejszoną wrażliwość badanych populacji wołka zbożowego i trojszyka ulca na deltametrynę oraz pirymifos metylowy w większości badanych populacji szkodników oraz kilka przypadków zmniejszonej wrażliwości pojedynczych chrząszczy wołka zbożowego na fosforowodór.

Słowa kluczowe: szkodniki magazynowe, odporność, insektycydy kontaktowe, fosforowodór

Instytut Ochrony Roślin - Państwowy Instytut Badawczy

Władysława Węgorka 20, 60-318 Poznań

${ }^{1}$ Zakład Entomologii

P.Olejarski@iorpib.poznan.pl

${ }^{2}$ Zakład Zoologii

P.Wegorek@iorpib.poznan.pl 


\section{Wstęp / Introduction}

Odporność na chemiczne środki ochrony roślin (ś.o.r.) dotyczy praktycznie wszystkich organizmów żywych, w tym szkodników magazynowych zasiedlających składowane zboża. Zjawisko to staje się poważnym problemem w coraz większej liczbie krajów. Przyczynę upatruje się w zmniejszającej się liczbie dostępnych substancji czynnych (s.cz.), a tym samym preparatów, na skutek wprowadzenia restrykcyjnych wymagań rejestracyjnych (Dyrektywa WE 128/2009; Rozporządzenie WE 1107/2009).

Obecnie w Polsce do ochrony zmagazynowanego ziarna zbóż zarejestrowane są tylko 2 preparaty kontaktowe (jeden zawiera pirymifos metylowy, a drugi deltametrynę) i 4 preparaty do fumigacji generujące fosforowodór (Rejestr ś.o.r. 2013).

W kraju prowadzono do tej pory niewiele badań w zakresie odporności szkodników magazynowych, głównie w odniesieniu do odporności wołka zbożowego (Sitophilus granarius L.) na fumiganty - bromek metylu i fosforowodór (Ignatowicz 1999). Równie mało jest publikacji naukowych $\mathrm{w}$ języku polskim na ten temat (Ignatowicz i Zettler 1997; Ignatowicz i Olejarski 2010, 2011; Olejarski i Ignatowicz 2011).

W celu stwierdzenia aktualnego poziomu odporności wśród szkodników magazynowych na s.cz. insektycydów stosowanych w Polsce, w Instytucie Ochrony Roślin Państwowym Instytucie Badawczym w Poznaniu (IOR PIB), w latach 2010-2012, prowadzono badania odporności dwóch szkodników: wołka zbożowego (S. granarius L.) i trojszyka ulca (Tribolium confusum Duv.).

\section{Materiały i metody / Materials and methods}

Szkodniki do badań pobierano $\mathrm{z}$ miejsc ich naturalnego występowania - głównie z magazynów zbożowych zlokalizowanych w różnych miejscach w Polsce. Były to zarówno obiekty profesjonalne o znacznej kubaturze, jak i małe, głównie zlokalizowane $\mathrm{w}$ gospodarstwach indywidualnych. Zbierano także informacje o wykonywanych w tych magazynach zabiegach dezynsekcyjnych.

Tabela 1. Pochodzenie populacji wołka zbożowego (S. granarius) i trojszyka ulca (T. confusum) w kolejnych latach badań 2010-2012

Table 1. The origin of populations of granary weevil ( $S$. granarius) and confused flour beetle (T. confusum) in following years of the study $2010-2012$

\begin{tabular}{c|c|c|c|c|c|c}
\hline & Lp. & Miejscowość & & Województwo \\
No. & Locality & Voivodeship & $\begin{array}{c}\text { Rodzaj magazynu zbożowego } \\
\text { Types of grain storages }\end{array}$ & $\begin{array}{c}\text { Zwalczanie } \\
\text { substancja czynna } \\
\text { Pest control } \\
\text { active substance }\end{array}$ & \multicolumn{2}{|c}{$\begin{array}{c}\text { Gatunek szkodnika } \\
\text { Insect pest species }\end{array}$} \\
\cline { 5 - 7 } & 2 & 3 & 4 & 5 & 6 & 7 \\
\hline 1 & 2 & Sranarius & T. confusum \\
\hline
\end{tabular}

\begin{tabular}{|c|c|c|c|c|c|c|}
\hline 1. & Winna Góra & wielkopolskie & $\begin{array}{l}\text { płaski i silos - flat and silo } \\
\text { gospodarstwo rolne - farm }\end{array}$ & $\begin{array}{c}\text { deltamethrin } \\
\text { pirimiphos-methyl }\end{array}$ & + & + \\
\hline 2. & Słupia Wielka & wielkopolskie & $\begin{array}{c}\text { płaski }- \text { flat } \\
\text { gospodarstwo rolne }- \text { farm }\end{array}$ & $\begin{array}{c}\text { deltamethrin } \\
\text { pirimiphos-methyl }\end{array}$ & + & - \\
\hline 3. & \begin{tabular}{|l|} 
Drzęczewo \\
Drugie
\end{tabular} & wielkopolskie & $\begin{array}{c}\text { płaski }- \text { flat } \\
\text { gospodarstwo rolne }- \text { farm }\end{array}$ & $\begin{array}{c}\text { bez ochrony } \\
\text { without pest control }\end{array}$ & + & - \\
\hline 4. & Poznań & wielkopolskie & $\begin{array}{c}\text { silos }- \text { silo } \\
\text { profesjonalny - professional }\end{array}$ & $\begin{array}{c}\text { deltamethrin } \\
\text { pirimiphos-methyl } \\
\text { phosphine }\end{array}$ & - & + \\
\hline 5. & Gorzykowo & wielkopolskie & $\begin{array}{c}\text { płaski - flat } \\
\text { gospodarstwo rolne }- \text { farm }\end{array}$ & $\begin{array}{l}\text { bez ochrony } \\
\text { without pest control }\end{array}$ & + & - \\
\hline 6. & Ręczno & łódzkie & $\begin{array}{c}\text { płaski - flat } \\
\text { profesjonalny - professional }\end{array}$ & $\begin{array}{l}\text { bez ochrony } \\
\text { without pest control }\end{array}$ & + & - \\
\hline 7. & Rozprza 1 & łódzkie & $\begin{array}{c}\text { płaski }- \text { flat } \\
\text { gospodarstwo rolne }- \text { farm }\end{array}$ & $\begin{array}{c}\text { deltamethrin } \\
\text { pirimiphos-methyl }\end{array}$ & + & - \\
\hline 8. & Rozprza 2 & łódzkie & $\begin{array}{c}\text { płaski }- \text { flat } \\
\text { gospodarstwo rolne }- \text { farm }\end{array}$ & $\begin{array}{c}\text { deltamethrin } \\
\text { pirimiphos-methyl }\end{array}$ & + & - \\
\hline 9. & Rozprza 3 & łódzkie & $\begin{array}{c}\text { płaski }- \text { flat } \\
\text { gospodarstwo rolne }- \text { farm }\end{array}$ & $\begin{array}{c}\text { deltamethrin } \\
\text { pirimiphos-methyl }\end{array}$ & + & - \\
\hline 10. & Suchożebry & mazowieckie & $\begin{array}{l}\text { płaski i silos - flat and silo } \\
\text { profesjonalny - professional }\end{array}$ & $\begin{array}{c}\text { deltamethrin } \\
\text { pirimiphos-methyl } \\
\text { phosphine }\end{array}$ & - & + \\
\hline 11. & Brzeg & opolskie & $\begin{array}{c}\text { silos }- \text { silo } \\
\text { profesjonalny }- \text { professional }\end{array}$ & phosphine & - & + \\
\hline 12. & Wrocław & dolnośląskie & $\begin{array}{c}\text { silos }- \text { silo } \\
\text { profesjonalny }- \text { professional }\end{array}$ & phosphine & - & + \\
\hline
\end{tabular}




\begin{tabular}{|c|c|c|c|c|c|c|}
\hline 1 & 2 & 3 & 4 & 5 & 6 & 7 \\
\hline \multicolumn{7}{|c|}{2011} \\
\hline 1. & Winna Góra & wielkopolskie & $\begin{array}{l}\text { płaski i silos - flat and silo } \\
\text { gospodarstwo rolne - farm }\end{array}$ & $\begin{array}{c}\text { deltamethrin } \\
\text { pirimiphos-methyl }\end{array}$ & + & + \\
\hline 2. & Poznań & wielkopolskie & $\begin{array}{c}\text { silos }- \text { silo } \\
\text { profesjonalny - professional }\end{array}$ & $\begin{array}{c}\text { deltamethrin } \\
\text { pirimiphos-methyl } \\
\text { phosphine }\end{array}$ & - & + \\
\hline 3. & Rybowo & wielkopolskie & $\begin{array}{c}\text { płaski }- \text { flat } \\
\text { gospodarstwo rolne }- \text { farm }\end{array}$ & $\begin{array}{l}\text { bez ochrony } \\
\text { without pest control }\end{array}$ & + & - \\
\hline 4. & $\begin{array}{l}\text { Piotrków } \\
\text { Trybunalski }\end{array}$ & łódzkie & $\begin{array}{c}\text { płaski }- \text { flat } \\
\text { gospodarstwo rolne }- \text { farm }\end{array}$ & $\begin{array}{l}\text { bez ochrony } \\
\text { without pest control }\end{array}$ & + & - \\
\hline 5. & Rozprza & łódzkie & $\begin{array}{c}\text { płaski - flat } \\
\text { gospodarstwo rolne }- \text { farm }\end{array}$ & $\begin{array}{c}\text { bez ochrony } \\
\text { without pest control }\end{array}$ & + & - \\
\hline 6. & Sulejów & łódzkie & $\begin{array}{c}\text { płaski - flat } \\
\text { gospodarstwo rolne }- \text { farm }\end{array}$ & $\begin{array}{l}\text { bez ochrony } \\
\text { without pest control }\end{array}$ & + & - \\
\hline 7. & Rzeszów & podkarpackie & $\begin{array}{c}\text { silos }- \text { silo } \\
\text { profesjonalny - professional }\end{array}$ & $\begin{array}{c}\text { deltamethrin } \\
\text { pirimiphos-methyl } \\
\text { phosphine }\end{array}$ & + & - \\
\hline 8. & Opole & opolskie & $\begin{array}{c}\text { silos }- \text { silo } \\
\text { profesjonalny - professional }\end{array}$ & phosphine & + & \\
\hline 9. & Wrocław & dolnośląskie & $\begin{array}{c}\text { silos }- \text { silo } \\
\text { profesjonalny - professional }\end{array}$ & phosphine & - & + \\
\hline \multicolumn{7}{|c|}{2012} \\
\hline 1. & Przebędowo & wielkopolskie & $\begin{array}{c}\text { płaski - flat } \\
\text { gospodarstwo rolne }- \text { farm }\end{array}$ & $\begin{array}{c}\text { bez ochrony } \\
\text { without pest control }\end{array}$ & + & - \\
\hline 2. & Poznań & wielkopolskie & $\begin{array}{c}\text { silos - silo } \\
\text { profesjonalny - professional }\end{array}$ & $\begin{array}{c}\text { deltamethrin } \\
\text { pirimiphos-methyl } \\
\text { phosphine }\end{array}$ & - & + \\
\hline 3. & Złotów & wielkopolskie & $\begin{array}{c}\text { silos - silo } \\
\text { gospodarstwo rolne }- \text { farm }\end{array}$ & $\begin{array}{c}\text { bez ochrony } \\
\text { without pest control }\end{array}$ & - & + \\
\hline 4. & Czarnków & wielkopolskie & $\begin{array}{c}\text { płaski }- \text { flat } \\
\text { gospodarstwo rolne }- \text { farm }\end{array}$ & pirimiphos-methyl & + & - \\
\hline 5. & Kruszwica & $\begin{array}{l}\text { kujawsko- } \\
\text { pomorskie }\end{array}$ & $\begin{array}{c}\text { płaski - flat } \\
\text { profesjonalny - professional }\end{array}$ & $\begin{array}{c}\text { deltamethrin } \\
\text { pirimiphos-methyl } \\
\text { phosphine }\end{array}$ & - & + \\
\hline 6. & $\begin{array}{l}\text { Piotrków } \\
\text { Trybunalski }\end{array}$ & łódzkie & $\begin{array}{c}\text { płaski - flat } \\
\text { gospodarstwo rolne }- \text { farm }\end{array}$ & $\begin{array}{c}\text { bez ochrony } \\
\text { without pest control }\end{array}$ & + & - \\
\hline 7. & Rajsko & łódzkie & $\begin{array}{c}\text { płaski }- \text { flat } \\
\text { gospodarstwo rolne }- \text { farm }\end{array}$ & pirimiphos-methyl & + & - \\
\hline 8. & Wielka Klonia & $\begin{array}{l}\text { kujawsko- } \\
\text { pomorskie }\end{array}$ & $\begin{array}{c}\text { płaski }- \text { flat } \\
\text { gospodarstwo rolne }- \text { farm }\end{array}$ & $\begin{array}{c}\text { deltamethrin } \\
\text { pirimiphos-methyl }\end{array}$ & + & - \\
\hline 9. & Żarzyn & lubuskie & $\begin{array}{l}\text { płaski i silos - flat and silo } \\
\text { profesjonalny - professional }\end{array}$ & $\begin{array}{c}\text { deltamethrin } \\
\text { pirimiphos-methyl } \\
\text { phosphine }\end{array}$ & + & - \\
\hline
\end{tabular}

Adresy podmiotów zajmujących się obrotem i magazynowaniem zbóż uzyskano z Wojewódzkich Inspektoratów Ochrony Roślin i Nasiennictwa, z Głównego Inspektoratu Jakości Handlowej Artykułów Rolno-Spożywczych oraz z Agencji Rynku Rolnego.

Zebrane $\mathrm{w}$ terenie szkodniki przewożono do laboratorium Zakładu Entomologii IOR - PIB i hodowano w celu rozmnożenia do liczebności niezbędnej do dalszych badań. W tym celu umieszczano je w szklanych słojach na odpowiednim pokarmie; chrząszcze wołka zbożowego na ziarnie pszenicy, a trojszyka ulca na mące. Szkodniki z każdej lokalizacji umieszczano w oddzielnych, izolo- wanych i opisanych słojach zakręcanych plastikowymi, perforowanymi nakrętkami. Słoje ze szkodnikami i pokarmem umieszczano w cieplarce, w temperaturze $26 \pm 1^{\circ} \mathrm{C}$, wilgotności względnej powietrza $75 \pm 5 \%$ i prowadzono hodowlę rozmnożeniową.

W badaniach użyto dostępne w handlu kontaktowe ś.o.r. zawierające s.cz. $\mathrm{z}$ grupy pyretroidów (preparat K-Obiol 25 EC) i z grupy związków fosforoorganicznych (preparat Actellic 500 EC). W badaniach nie stosowano handlowych preparatów fosforowodorowych tylko specjalną formę użytkową fosforku magnezu, przeznaczoną do testów odpornościowych. 
Tabela 2. Wrażliwość na deltametrynę i pirymifos metylowy chrząszczy wołka zbożowego (S. granarius) zebranych w kolejnych latach badań 2010-2012

Table 2. Susceptibility to deltamethrin and pirimiphios-methyl of granary weevil (S. granarius) collected in following years of the study 2010-2012

\begin{tabular}{|c|c|c|c|c|c|c|c|c|c|c|c|c|c|}
\hline \multirow{4}{*}{$\begin{array}{l}\text { Lp. } \\
\text { No. }\end{array}$} & \multirow{4}{*}{$\begin{array}{l}\text { Miejscowość } \\
\text { Locality }\end{array}$} & \multicolumn{12}{|c|}{$\begin{array}{l}\text { Aktywność chrząszczy po } 6 \text { godzinach (liczba testowanych osobników }-400 \text { szt.) } \\
\text { Activity of insects after } 6 \text { hours (number of tested insect pest }-400 \text { pcs) }\end{array}$} \\
\hline & & \multicolumn{6}{|c|}{ deltamethrin } & \multicolumn{6}{|c|}{ pirimiphos-methyl } \\
\hline & & \multicolumn{3}{|c|}{$\begin{array}{c}\text { dawka etykietowa } \\
\text { labeling dose } \\
{\left[60 \mathrm{ml} / 100 \mathrm{~m}^{2}\right]}\end{array}$} & \multicolumn{3}{|c|}{$\begin{array}{c}1 / 2 \text { dawki etykietowej } \\
1 / 2 \text { labeling dose } \\
{\left[30 \mathrm{ml} / 100 \mathrm{~m}^{2}\right]}\end{array}$} & \multicolumn{3}{|c|}{$\begin{array}{l}\text { dawka etykietowa } \\
\text { labeling dose } \\
{\left[1000 \mathrm{ml} / 1000 \mathrm{~m}^{2}\right]}\end{array}$} & \multicolumn{3}{|c|}{$\begin{array}{c}1 / 2 \text { dawki etykietowej } \\
1 / 2 \text { labeling dose } \\
{\left[500 \mathrm{ml} / 1000 \mathrm{~m}^{2}\right]}\end{array}$} \\
\hline & & WR & PR & FS & WR & PR & FS & WR & PR & FS & WR & PR & FS \\
\hline \multicolumn{14}{|c|}{2010} \\
\hline 1. & Winna Góra & 0 & 23 & 377 & 0 & 400 & 0 & 0 & 0 & 400 & 0 & 0 & 400 \\
\hline 2. & Słupia Wielka & 0 & 0 & 400 & 0 & 400 & 0 & 0 & 0 & 400 & 0 & 0 & 400 \\
\hline 3. & $\begin{array}{l}\text { Drzęczewo } \\
\text { Drugie }\end{array}$ & 0 & 0 & 400 & 0 & 400 & 0 & 0 & 0 & 400 & 0 & 0 & 400 \\
\hline 4. & Gorzykowo & 0 & 0 & 400 & 0 & 400 & 0 & 0 & 0 & 400 & 0 & 0 & 400 \\
\hline 5. & Ręczno & 0 & 0 & 400 & 0 & 400 & 0 & 0 & 0 & 400 & 0 & 0 & 400 \\
\hline 6. & Rozprza 1 & 0 & 0 & 400 & 0 & 400 & 0 & 0 & 0 & 400 & 0 & 0 & 400 \\
\hline 7. & Rozprza 2 & 0 & 0 & 400 & 0 & 400 & 0 & 0 & 0 & 400 & 0 & 0 & 400 \\
\hline 8. & Rozprza 3 & 0 & 0 & 400 & 0 & 400 & 0 & 0 & 0 & 400 & 0 & 0 & 400 \\
\hline
\end{tabular}

\begin{tabular}{l|l|c|c|c|c|c|c|c|c|c|c|c|c}
\hline 1. & Winna Góra & 0 & 8 & 392 & 0 & 400 & 0 & 0 & 400 & 0 & 0 & 400 & 0 \\
\hline 2. & Rybowo & 0 & 0 & 400 & 0 & 400 & 0 & 0 & 400 & 0 & 0 & 400 & 0 \\
\hline 3. & $\begin{array}{l}\text { Piotrków } \\
\text { Trybunalski }\end{array}$ & 3 & 4 & 393 & 1 & 23 & 376 & 0 & 400 & 0 & 0 & 400 & 0 \\
\hline 4. & Rozprza & 0 & 0 & 400 & 0 & 30 & 370 & 0 & 400 & 0 & 0 & 400 & 0 \\
\hline 5. & Sulejów & 0 & 0 & 400 & 0 & 18 & 382 & 0 & 400 & 0 & 0 & 400 & 0 \\
\hline 6. & Rzeszów & 0 & 5 & 395 & 0 & 72 & 328 & 0 & 400 & 0 & 0 & 400 & 0 \\
\hline 7. & Opole & 0 & 2 & 398 & 0 & 390 & 10 & 0 & 400 & 0 & 0 & 400 & 0 \\
\hline
\end{tabular}

\begin{tabular}{|c|c|c|c|c|c|c|c|c|c|c|c|c|c|}
\hline \multicolumn{14}{|c|}{2012} \\
\hline 1. & Przebędowo & 0 & 0 & 400 & 0 & 0 & 400 & 0 & 400 & 0 & 0 & 400 & 0 \\
\hline 2. & Czarnków & 0 & 0 & 400 & 0 & 5 & 395 & 0 & 400 & 0 & 0 & 400 & 0 \\
\hline 3. & $\begin{array}{l}\text { Piotrków } \\
\text { Trybunalski }\end{array}$ & 18 & 123 & 259 & 0 & 165 & 235 & 0 & 400 & 0 & 0 & 400 & 0 \\
\hline 4. & Rajsko & 0 & 0 & 400 & 0 & 21 & 379 & 0 & 400 & 0 & 0 & 400 & 0 \\
\hline 5. & Wielka Klonia & 0 & 0 & 400 & 0 & 0 & 400 & 0 & 400 & 0 & 0 & 400 & 0 \\
\hline 6. & Żarzyn & 0 & 0 & 400 & 0 & 0 & 400 & 0 & 400 & 0 & 0 & 400 & 0 \\
\hline
\end{tabular}

WR - całkowicie odporne, chodza, brak oznak zatrucia czy paraliżu - wholly resistance, can walk, without symptoms of poisoning or paralysis PR - częściowo odporne, żyją, sparaliżowane, nie chodzą, poruszają odnóżami - partially resistant, alive, paralysis, dont walk, paralyzed FS - w pełni wrażliwe, całkowicie nieodporne, bez oznak życia - fully susceptible, not resistant, without symptoms of life

Testy odporności na s.cz. kontaktowych ś.o.r. prowadzono na chrząszczach wołka zbożowego oraz na larwach i chrząszczach trojszyka ulca, a testy odporności na fosforowodór na chrząszczach wołka zbożowego i trojszyka ulca .

Badania odporności na insektycydy kontaktowe wykonywano według metodyki IRAC nr 6 (Insecticide Resistance Action Committee - Komitet do Spraw Odporności Owadów), którą opracowano w Natural Resources Institute (NRI) w Anglii (Metodyka IRAC 2009), a która umożliwia badanie odporności chrząszczy magazynowych. Badania odporności owadów na kontaktowe ś.o.r. prowadzono w 4 powtórzeniach po 10 szalek, w każdej po 10 osobników badanego gatunku. Prowadzono je w temperaturze $25 \pm 2{ }^{\circ} \mathrm{C}$ i wilgotności względnej powietrza $70 \pm 5 \%$.

Badania odporności owadów na fosforowodór wykonywano według metodyki opracowanej przez firmę Detia Degesch GmbH (Metodyka Detia Degesch 2009) i w specjalnie w testerach „Phosphine Resistance Test Kit”. Badania te wykonywano przy stężeniu gazu wynoszącym 3000 ppm, przy którym możliwe jest określenie, czy badana populacja jest lub nie jest odporna na fosforowodór (Marketing News 2005). 
Badania odporności owadów na fosforowodór prowadzono w 5 powtórzeniach po 20 osobników każdego z badanych gatunków. Prowadzono je w temperaturze $20-25^{\circ} \mathrm{C}$.

\section{Wyniki i dyskusja / Results and discussion}

W badaniach prowadzonych w latach 2010-2012 zebrano szkodniki z 30 lokalizacji. W 2010 r. z 12, w 2011 r. z 9 i w 2012 r. z 9 lokalizacji. Szkodniki zbierano z terenu 8 województw: dolnośląskiego, kujawsko-pomorskiego, lubuskiego, łódzkiego, mazowieckiego, opolskiego, podkarpackiego i wielkopolskiego. Najwięcej prób zebrano z województwa wielkopolskiego (tab. 1).

Chrząszcze wołka zbożowego zebrano w sumie z 21 lokalizacji, w 2010 r. z 8, w 2011 r. z 7 i w 2012 r. z 6 lokalizacji. Chrząszcze trojszyka ulca zebrano w sumie z 11 lo-

Tabela 3. Wrażliwość na deltametrynę i pirymifos metylowy larw i chrząszczy trojszyka ulca (T. confusum) zebranych w kolejnych latach badań 2010-2012

Table 3. Susceptibility to deltamethrin and pirymiphos-methyl of larvae and beetles of confused flour beetle (T. confusum) collected in following years of the study 2010-2012

\begin{tabular}{|c|c|c|c|c|c|c|c|c|c|c|c|c|c|}
\hline \multirow{4}{*}{$\begin{array}{l}\text { Lp. } \\
\text { No. }\end{array}$} & \multirow{4}{*}{$\begin{array}{l}\text { Miejscowość } \\
\text { Locality }\end{array}$} & \multicolumn{12}{|c|}{$\begin{array}{l}\text { Aktywność larw po } 5 \text { godzinach (liczba testowanych osobników }-400 \text { szt.) } \\
\text { Activity of larvae after } 5 \text { hours (number of tested insect pest }-400 \text { pcs) }\end{array}$} \\
\hline & & \multicolumn{6}{|c|}{ deltamethrin } & \multicolumn{6}{|c|}{ pirimiphos-methyl } \\
\hline & & \multicolumn{3}{|c|}{$\begin{array}{c}\text { dawka etykietowa } \\
\text { labeling dose } \\
{\left[60 \mathrm{ml} / 100 \mathrm{~m}^{2}\right]}\end{array}$} & \multicolumn{3}{|c|}{$\begin{array}{c}1 / 2 \text { dawki etykietowej } \\
1 / 2 \text { labeling dose } \\
{\left[30 \mathrm{ml} / 100 \mathrm{~m}^{2}\right]}\end{array}$} & \multicolumn{3}{|c|}{$\begin{array}{c}\text { dawka etykietowa } \\
\text { labeling dose } \\
{\left[1000 \mathrm{ml} / 1000 \mathrm{~m}^{2}\right]}\end{array}$} & \multicolumn{3}{|c|}{$\begin{array}{c}1 / 2 \text { dawki etykietowej } \\
1 / 2 \text { labeling dose } \\
{\left[500 \mathrm{ml} / 1000 \mathrm{~m}^{2}\right]}\end{array}$} \\
\hline & & WR & PR & FS & WR & PR & FS & WR & PR & FS & WR & PR & FS \\
\hline \multicolumn{14}{|c|}{2010} \\
\hline 1. & Winna Góra & 0 & 400 & 0 & 0 & 400 & 0 & 0 & 400 & 0 & 0 & 400 & 0 \\
\hline 2. & Poznań & 0 & 400 & 0 & 0 & 400 & 0 & 0 & 400 & 0 & 0 & 400 & 0 \\
\hline 3. & Suchożebry & 0 & 400 & 0 & 0 & 400 & 0 & 0 & 400 & 0 & 0 & 400 & 0 \\
\hline 4. & Brzeg & 0 & 400 & 0 & 0 & 400 & 0 & 0 & 400 & 0 & 0 & 400 & 0 \\
\hline 5. & Wrocław & 0 & 400 & 0 & 0 & 400 & 0 & 0 & 400 & 0 & 0 & 400 & 0 \\
\hline \multicolumn{14}{|c|}{2011} \\
\hline 1. & Winna Góra & 0 & 198 & 202 & 0 & 400 & 0 & 0 & 0 & 400 & 0 & 400 & 0 \\
\hline 2. & Poznań & 0 & 195 & 205 & 0 & 400 & 0 & 0 & 78 & 322 & 0 & 400 & 0 \\
\hline 3. & Wrocław & 0 & 211 & 189 & 0 & 400 & 0 & 0 & 69 & 331 & 0 & 400 & 0 \\
\hline \multicolumn{14}{|c|}{2012} \\
\hline 1. & Poznań & 0 & 400 & 0 & 0 & 400 & 0 & 0 & 392 & 8 & 0 & 400 & 0 \\
\hline 2. & Złotów & 0 & 400 & 0 & 0 & 400 & 0 & 0 & 15 & 385 & 0 & 400 & 0 \\
\hline 3. & Kruszwica & 0 & 175 & 225 & 0 & 320 & 80 & 0 & 400 & 0 & 0 & 392 & 8 \\
\hline & & \multicolumn{12}{|c|}{$\begin{array}{l}\text { Aktywność chrząszczy po } 5 \text { godzinach (liczba testowanych osobników - po } 400 \text { szt.) } \\
\text { Activity of beetles after } 5 \text { hours (number of tested insect pest }-400 \text { pcs) }\end{array}$} \\
\hline
\end{tabular}

\begin{tabular}{l|l|l|l|l|l|l|l|l|l|l|l|l|l}
\hline 1. & Winna Góra & 0 & 400 & 0 & 0 & 400 & 0 & 0 & 0 & 400 & 0 & 400 & 0 \\
\hline 2. & Pozná́ & 0 & 400 & 0 & 0 & 400 & 0 & 0 & 0 & 400 & 0 & 400 & 0 \\
\hline 3. & Suchożebry & 0 & 400 & 0 & 0 & 400 & 0 & 0 & 10 & 390 & 0 & 400 & 0 \\
\hline 4. & Brzeg & 0 & 400 & 0 & 0 & 400 & 0 & 0 & 50 & 350 & 0 & 400 & 0 \\
\hline 5. & Wrocław & 0 & 400 & 0 & 0 & 400 & 0 & 0 & 156 & 244 & 0 & 400 & 0 \\
\hline
\end{tabular}

\begin{tabular}{r|l|l|l|l|l|l|}
\hline 5. & Wrocław & 0 & 400 & 0 & 0 & 400 \\
\hline
\end{tabular}

\begin{tabular}{l|l|l|l|l|l|l|l|l|l|l|l|l|l}
\hline 1. & Winna Góra & 0 & 190 & 210 & 0 & 400 & 0 & 0 & 0 & 400 & 0 & 400 & 0 \\
\hline 2. & Poznań & 0 & 189 & 211 & 0 & 400 & 0 & 0 & 56 & 344 & 0 & 400 & 0 \\
\hline 3. & Wrocław & 0 & 200 & 200 & 0 & 400 & 0 & 0 & 89 & 311 & 0 & 400 & 0 \\
\hline
\end{tabular}

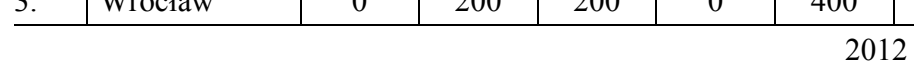

\begin{tabular}{l|l|c|c|c|c|c|c|c|c|c|c|c|c}
\hline 1. & Poznań & 0 & 400 & 0 & 0 & 371 & 29 & 0 & 400 & 0 & 0 & 400 & 0 \\
\hline 2. & Złotów & 0 & 400 & 0 & 0 & 400 & 0 & 0 & 0 & 400 & 0 & 400 & 0 \\
\hline 3. & Kruszwica & 0 & 170 & 230 & 0 & 348 & 52 & 0 & 400 & 0 & 0 & 400 & 0 \\
\hline
\end{tabular}

WR - całkowicie odporne, chodza, brak oznak zatrucia czy paraliżu - wholly resistance, can walk, without symptoms of poisoning or paralysis PR - częściowo odporne, żyją, sparaliżowane, nie chodzą, poruszają odnóżami - partially resistant, alive, paralysis, dont walk, paralyzed FS - w pełni wrażliwe, całkowicie nieodporne, bez oznak życia - fully susceptible, not resistant, without symptoms of life 
Tabela 4. Wrażliwość na fosforowodór chrząszczy wołka zbożowego (S. granarius) i trojszyka ulca (T. confusum) zebranych w kolejnych latach badań 2010-2012

Table 4. Susceptibility to phosphine of granary weevil (S. granarius) and confused flour beetle (T. confusum) collected in following years of the study $2010-2012$

\begin{tabular}{|c|c|c|c|c|c|c|c|}
\hline \multirow{4}{*}{$\begin{array}{l}\text { Lp. } \\
\text { No. }\end{array}$} & \multirow{4}{*}{$\begin{array}{c}\text { Miejscowość } \\
\text { Locality }\end{array}$} & \multicolumn{3}{|c|}{$\begin{array}{c}\text { Aktywność szkodników po } 12 \text { minutach } \\
\text { (liczba testowanych osobników }-100 \text { szt.) } \\
\text { Activity of insects after } 12 \text { minutes } \\
\text { (number of tested insect pest }-100 \text { pcs) }\end{array}$} & \multicolumn{3}{|c|}{$\begin{array}{c}\text { Aktywność chrząszczy po } 8 \text { minutach } \\
\text { (liczba testowanych osobników - } 100 \text { szt.) } \\
\text { Activity of beetles after } 8 \text { minutes } \\
\text { (number of tested insect pest }-100 \text { pcs) }\end{array}$} \\
\hline & & \multicolumn{3}{|c|}{ S. granarius } & \multicolumn{3}{|c|}{ T. confusum } \\
\hline & & \multicolumn{3}{|c|}{$\begin{array}{c}\text { stężenie fosforowodoru } \\
\text { concentration of phosphine } \\
{[3000 \mathrm{ppm}]}\end{array}$} & \multicolumn{3}{|c|}{$\begin{array}{c}\text { stężenie fosforowodoru } \\
\text { concentration of phosphine } \\
{[3000 \mathrm{ppm}]}\end{array}$} \\
\hline & & WR & PR & $\mathrm{FS}$ & WR & PR & FS \\
\hline \multicolumn{8}{|c|}{2010} \\
\hline 1. & Poznań & - & - & - & 0 & 0 & 100 \\
\hline 2. & Suchożebry & - & - & - & 0 & 0 & 100 \\
\hline 3. & Brzeg & - & - & - & 0 & 0 & 100 \\
\hline 4. & Wrocław & - & - & - & 0 & 0 & 100 \\
\hline 5. & Winna Góra & 0 & 3 & 97 & 0 & 0 & 100 \\
\hline 6. & Słupia Wielka & 0 & 3 & 97 & - & - & - \\
\hline 7. & $\begin{array}{l}\text { Drzęczewo } \\
\text { Drugie }\end{array}$ & 0 & 4 & 96 & - & - & - \\
\hline 8. & Gorzykowo & 0 & 0 & 100 & - & - & - \\
\hline 9. & Ręczno & 0 & 12 & 88 & - & - & - \\
\hline 10. & Rozprza 1 & 0 & 13 & 87 & - & - & - \\
\hline 11. & Rozprza 2 & 0 & 10 & 90 & - & - & - \\
\hline 12. & Rozprza 3 & 0 & 6 & 94 & - & - & - \\
\hline \multicolumn{8}{|c|}{2011} \\
\hline 1. & Poznań & - & - & - & 0 & 1 & 99 \\
\hline 2. & Wrocław & - & - & - & 0 & 1 & 99 \\
\hline 3. & Winna Góra & 0 & 1 & 99 & 0 & 0 & 100 \\
\hline 4. & Rybowo & 0 & 0 & 100 & - & - & - \\
\hline 5. & $\begin{array}{l}\text { Piotrków } \\
\text { Trybunalski }\end{array}$ & 0 & 0 & 100 & - & - & - \\
\hline 6. & Rozprza & 0 & 0 & 100 & - & - & - \\
\hline 7. & Sulejów & 0 & 0 & 100 & - & - & - \\
\hline 8. & Rzeszów & 0 & 10 & 90 & - & - & - \\
\hline 9. & Opole & 0 & 12 & 88 & - & - & - \\
\hline \multicolumn{8}{|c|}{2012} \\
\hline 1. & Poznań & - & - & - & 0 & 2 & 98 \\
\hline 2. & Złotów & - & - & - & 0 & 0 & 100 \\
\hline 3. & Kruszwica & - & - & - & 0 & 3 & 97 \\
\hline 4. & Przebędowo & 0 & 0 & 100 & - & - & - \\
\hline 5. & Czarnków & 0 & 0 & 100 & - & - & - \\
\hline 6. & $\begin{array}{l}\text { Piotrków } \\
\text { Trybunalski }\end{array}$ & 0 & 0 & 100 & - & - & - \\
\hline 7. & Rajsko & 0 & 0 & 100 & - & - & - \\
\hline 8. & Wielka Klonia & 0 & 0 & 100 & - & - & - \\
\hline 6. & Żarzyn & 0 & 0 & 100 & - & - & - \\
\hline
\end{tabular}

WR - całkowicie odporne, chodzą, brak oznak zatrucia czy paraliżu - wholly resistance, can walk, without symptoms of poisoning or paralysis PR - częściowo odporne, żyją, sparaliżowane, nie chodzą, poruszają odnóżami - partially resistant, alive, paralysis, dont walk, paralyzed FS - w pełni wrażliwe, całkowicie nieodporne, bez oznak życia - fully susceptible, not resistant, without symptoms of life 
kalizacji, w 2010 r. z 5, w 2011 r. z 3 i w 2012 r. z 3 lokalizacji.

Zabiegi zwalczania szkodników magazynowych w obiektach, z których pobierano owady do badań prowadzono zarówno przy użyciu kontaktowych ś.o.r. zawierających deltametrynę i pirymifos metylowy, jak i gazowych środków fosforowodorowych.

Preparat zawierający deltametrynę stosowano w magazynach, w 14 lokalizacjach, a zawierający pirymofos metylowy w 16 lokalizacjach. Częstsze stosowanie środka zawierającego pirymofos metylowy może wynikać z tego, że jego rejestracja dopuszcza aplikację zarówno bezpośrednio na ziarno zbóż, jak i do zwalczania szkodników w pustych magazynach. Rejestracja środka zawierającego deltametrynę dopuszcza stosowanie go tylko do bezpośredniej ochrony ziarna zbóż (Rejestr ś.o.r. 2013). W 18 lokalizacjach znajdowały się mniejsze magazyny w gospodarstwach rolników indywidualnych, a w 12 lokalizacjach magazyny profesjonalne, zwykle o dużej kubaturze i odpowiednio wyposażone, z których w 11 prowadzono zabiegi zwalczania $\mathrm{z}$ użyciem gazowych ś.o.r. W 10 lokalizacjach nie prowadzono żadnego chemicznego zwalczania szkodników i były to magazyny zlokalizowane, w większości w gospodarstwach rolników indywidualnych.

Stwierdzono, że chrząszcze wołka zbożowego pochodzące z większości badanych populacji były wrażliwe i w pełni nieodporne na deltametrynę zastosowaną $\mathrm{w}$ pełnej dawce etykietowej. W dwóch populacjach zebranych w 2011 i 2012 r. pochodzących z tej samej lokalizacji zaobserwowano jednak odporność pojedynczych osobników. Dla dawki deltametryny obniżonej o połowę wszystkie populacje wołka zbożowego zebrane w $2010 \mathrm{r}$. wykazywały zmniejszoną wrażliwość. Wśród populacji zebranych w 2011 i 2012 r. niektóre wykazywały pełną, a niektóre obniżoną wrażliwość. W jednej populacji zebranej w $2011 \mathrm{r}$. stwierdzono jednego chrząszcza odpornego (tab. 2).

W badaniach stwierdzono, że chrzaszcze wołka zbożowego pochodzące z populacji zebranych w $2010 \mathrm{r}$. były w pełni wrażliwe i nieodporne na pirymifos metylowy zastosowany w pełnej dawce etykietowej, jak i w dawce obniżonej o połowę. Populacje zebrane w 2011 i 2012 r. wykazywały zmniejszoną wrażliwość. Dla obu zastosowanych dawek pirymifosu metylowego nie stwierdzono przypadków odporności.

Stwierdzono również, że większość populacji trojszyka ulca, zarówno chrząszcze, jak i larwy, wykazywała zmniejszoną wrażliwość na deltametrynę zastosowaną w dawce pełnej i obniżonej o połowę. Dla obu zastosowanych dawek deltametryny nie stwierdzono przypadków odporności (tab. 2).

Przeprowadzone badania wykazały, że większość larw z populacji trojszyka ulca zebranych w latach: 2010, 2011 i 2012 wykazywała zmniejszoną wrażliwość na pirymifos metylowy zastosowany $\mathrm{w}$ dawce pełnej $\mathrm{i}$ obniżonej o połowę. Większość chrząszczy z badanych populacji trojszyka ulca była wrażliwa i nieodporna na pełną dawkę pirymifosu metylowego, natomiast $\mathrm{w}$ przypadku zastosowania dawki o połowę mniejszej wykazywała zmniejszoną wrażliwość. Dla obu zastosowanych dawek pirymifosu metylowego nie stwierdzono przypadków odporności (tab. 3).
Z przeprowadzonych badań wynika także, że zarówno chrząszcze wołka zbożowego, jak i trojszyka ulca w większości badanych populacji były wrażliwe i w pełni nieodporne na fosforowodór zastosowany $\mathrm{w}$ dawce 3000 ppm (tab. 4). Większość chrząszczy po określonym czasie obserwacji nie wykazywała żadnej aktywności. Stwierdzono tylko pojedyncze osobniki wykazujące zmniejszoną wrażliwość wśród zebranych w 2010 i 2011 r. populacji wołka zbożowego i wśród zebranych w 2011 i 2012 r. populacji trojszyka ulca. Nie zaobserwowano jednak przypadków pełnej odporności. Obecnie zabiegi fumigacji wykonywane są niezbyt często. Większość zwykle interwencyjnie, po stwierdzeniu szkodników (Ignatowicz i wsp. 2009).

\section{Wnioski / Conclusions}

1. Zwalczanie szkodników w magazynach zbożowych prowadzone było zarówno $\mathrm{z}$ użyciem kontaktowych, jak i gazowych ś.o.r.; częściej stosowany był preparat zawierający pirymifos metylowy niż zawierający deltametrynę; zabiegi $\mathrm{z}$ użyciem gazowych środków fosforowodorowych prowadzone były tylko w magazynach profesjonalnych.

2. Stwierdzono dwa przypadki odporności pojedynczych chrzązzczy wołka zbożowego (S. granarius) na deltametrynę, z populacji zebranych w 2011 i 2012 r. i pochodzących z tej samej lokalizacji oraz zmniejszoną wrażliwość wśród niektórych populacji wołka na tę s.cz. zastosowaną $\mathrm{w}$ dawce obniżonej o połowę.

3. Nie stwierdzono pełnej odporności chrząszczy wołka zbożowego na pirymifos metylowy zastosowany w dawce zalecanej i zmniejszonej o połowe, stwierdzono natomiast zmniejszoną wrażliwość niektórych populacji wołka na pirymifos metylowy zastosowany w dawce obniżonej o połowę.

4. Nie stwierdzono odporności badanych populacji trojszyka ulca (T. confusum), zarówno chrząszczy, jak i larw, na deltametrynę i pirymifos metylowy w dawkach pełnych i obniżonych o połowę.

5. Stwierdzono zmniejszoną wrażliwość większości badanych populacji trojszyka ulca, zarówno chrząszczy, jak i larw, na deltametrynę zastosowaną w pełnej i obniżonej o połowę dawce.

6. Stwierdzono, że większość larw badanych populacji trojszyka ulca wykazywała zmniejszoną wrażliwość na pirymifos metylowy zastosowany $\mathrm{w}$ dawce pełnej i obniżonej o połowę.

7. Nie stwierdzono odporności zebranych populacji wołka zbożowego i trojszyka ulca na fosforowodór w stężeniu 3000 ppm, tylko pojedyncze osobniki niektórych populacji tych szkodników wykazały zmniejszoną wrażliwość.

Praca naukowa finansowana ze środków na naukę w latach 2009-2012 jako projekt badawczy własny nr N N310 118437, Badanie odporności owadzich szkodników magazynowych na substancje aktywne insektycydów stosowanych w Polsce do ochrony magazynowanego ziarna zbóż jako podstawa zapewnienia bezpieczeństwa żywności. 


\section{Literatura / References}

Dyrektywa WE 128/2009. Dyrektywa Parlamentu Europejskiego i Rady 2009/128/WE z dnia 21 października 2009 r. ustanawiająca ramy wspólnotowego działania na rzecz zrównoważonego stosowania pestycydów. Dziennik Urzędowy Unii Europejskiej L 309 , Tom 52, z 24 listopada 2009: 71-86.

Ignatowicz S. 1999. Cases of phosphine resistance in the grain weevil Sitophilus granarius found in Poland. p. 625-630. In: Stored Product Protection: Proc. 7th International Working Conference on Stored-Product Protection. P.R. China, Beijing,14-19 October 1998, 2003 pp.

Ignatowicz S., Oboza S., Olejarski P. 2009. Rachunek ekonomiczny zabiegów fumigacji produktów spożywczych. [Economical account for food product fumigation]. Prog. Plant Prot./Post. Ochr. Roślin 49 (4): 1617-1621.

Ignatowicz S., Olejarski P. 2010. Konsekwencje wprowadzenia nowych przepisów Unii Europejskiej dla ochrony zmagazynowanych zbóż. [Consequences of new European Union legislations for stored grain protection]. Prog. Plant Prot./Post. Ochr. Roślin 50 (2): $547-554$.

Ignatowicz S., Olejarski P. 2011. Problem odporności szkodników magazynowych na fosforowodór. [Problem of stored product pests' resistance to phosphine]. Prog. Plant Prot./Post. Ochr. Roślin 51 (4): 1537-1554.

Ignatowicz S., Zettler J.L. 1997. Zapobieganie powstawaniu ras odpornych na fosforowodór u szkodników magazynowych. [Management of phosphine resistant strains of stored product pests]. Prog. Plant Prot./Post. Ochr. Roślin 37 (1): 138-143.

Marketing News 2005. Detia Degesch. Marketing News. Issue II. p. 5-6. Laudenbach, Germany. http://www.novochem.hu/degesch/ downloads/Marketing\%20News2.pdf, 8 pp, accessed: 04.01.2013.

Metodyka Detia Degesch 2009. Phosphine Resistance Test Kit. Directions for Use. Detia Degesch GmbH. Laudenbach, Germany. http://www.detia-degesch.de/downloads/6/Resistenztest-Bedienungs_engl.pdf, 15 pp, accessed: 04.01.2013.

Metodyka IRAC 2009. Beetles damaging stored products - all stages. Method No 6. Version: 3 (June 2009). IRAC Susceptibility Test Methods Series. http://www.irac-online.org/content/uploads/2009/09/Method_006_v3_june09.pdf, 3 pp, accessed: 04.01.2013.

Olejarski P., Ignatowicz S. 2011. Integrowana metoda zwalczania szkodników magazynowych podstawą zapewnienia wysokiej jakości przechowywanego ziarna zbóż. [IPM as a principle to ensure the high quality of stored grain]. Prog. Plant Prot./Post. Ochr. Roślin 51 (4): 1879-1885.

Rejestr ś.o.r. 2013. Rejestr środków ochrony roślin dopuszczonych do obrotu zezwoleniem Ministra Rolnictwa i Rozwoju Wsi. Ministerstwo Rolnictwa i Rozwoju Wsi. Warszawa. http://www.bip.minrol.gov.pl/DesktopDefault.aspx?TabOrgId=647\&LangId=0, dostęp: 04.01.2013.

Rozporządzenie WE 1107/2009. Rozporządzenie Parlamentu Europejskiego i Rady (WE) nr 1107/2009 z dnia 21 października 2009 r. dotyczące wprowadzania do obrotu środków ochrony roślin i uchylające dyrektywy Rady 79/117/EWG i 91/414/EWG. Dziennik Urzędowy Unii Europejskiej L 309, Tom 52, z 24 listopada 2009: 1-50. 